\title{
APPLICATION OF THE 2014 BETHESDA SYSTEM FOR REPORTING OF CERVICAL/VAGINAL CYTOLOGICAL LESIONS
}

\author{
Pratima Kujur ${ }^{1}$, Chandrakala Joshi \\ ${ }_{1}^{1}$ Associate Professor, Department of Pathology, Jawaharalal Nehru Memorial Medical College, Raipur, Chhattisgarh. \\ ${ }^{2}$ Associate Professor, Department of Pathology, Jawaharalal Nehru Memorial Medical College, Raipur, Chhattisgarh.
}

\section{ABSTRACT}

Pap smear (Conventional smear) is the most widely used cervical cancer screening test in the world. Negative intraepithelial lesion for malignancy, squamous intraepithelial lesion and cervical cancer remain important health problems for women worldwide. In developing countries like India, there is a great need for mass screening program for cervical lesion.

\section{AIMS AND OBJECTIVES \\ To assess the clinician utility of The 2014 Bethesda System Reporting of cervical and vaginal epithelial abnormalities.}

\section{MATERIAL AND METHODS} 2014.

All the cervical/vaginal cytology smears reported were retrieved and reviewed in the duration from 2007, 2008, 2009 and

\section{RESULTS}

A total number of 1700 cases of Pap smears were retrieved during period of study, out of which $90.0 \%$ were satisfactory for evaluation; $35.5 \%$ were within normal limit and 55.6\% were NILM. A few (8.14\%) of the cases were reported as squamous intraepithelial lesion; $0.5 \%$ as atypical squamous cells and $0.19 \%$ were reported as atypical glandular cells.

\section{CONCLUSION}

Pap smear is a proven tested tool for making an early diagnosis and treating cervical cancer in early stage. Thus, Pap smear is simple, less expensive diagnostics tool suitable for implementation in India.

\section{KEYWORDS}

Atypical Glandular Cells, Atypical Squamous Cells, Cervical/Vaginal Cytology, Carcinoma of Cervix, Conventional Pap Smear.

HOW TO CITE THIS ARTICLE: Pratima Kujur, Chandrakala Joshi. "Application of the 2014 Bethesda System for Reporting of Cervical/Vaginal Cytological Lesions." Journal of Evolution of Medical and Dental Sciences 2015; Vol. 4, Issue 98, December 07; Page: 16366-16371, DOI: 10.14260/jemds/2015/2419

\section{INTRODUCTION}

The examination of exfoliated cervical and vaginal cells for the detection of premalignant and malignant diseases has been performed for more than 50 years. ${ }^{1}$ This screening method is commonly referred to as the Pap smear named for George N. Papanicolaou, who in 1923 described malignant cells in vaginal fluid aspirated from the fornix and pursued the development of screening procedure. The sampling procedure is designed to collect an adequate number of representative well-preserved epithelial cells including cells from the transformation zone. ${ }^{2}$ The results of the Papanicolaou smear are communicated to the clinician utilizing a format and terminology formulated by the National Cancer Institute workshop (Developed in 1988 and revised in 1991) and referred to as the Bethesda System. Each cluster composed of a minimum of at least five appropriate cells is considered an adequate endocervical/transformation zone of component. A minimum of two clusters of well-preserved endocervical and a statement of a key component in the Bethesda System classification of cervical smears. ${ }^{3}$ Again revised in 2001 and in 2014. The Worldwide HPV prevalence in cervical carcinoma is $99.7 \%{ }^{4}$

Financial or Other, Competing Interest: None.

Submission 20-11-2015, Peer Review 21-11-2015,

Acceptance 01-12-2015, Published 07-12-2015.

Corresponding Author:

Dr. Chandrakala Joshi,

A/210, Ekta Parisar,

Mal Viyanagar Durg, Chhattisgarh.

E-mail: ckj242@gmail.com

DOI:10.14260/jemds/2015/2419
In developed countries such as USA, $85 \%$ of women had at least one Pap test through their lifetime, but this rate is only $5 \%$ in the developing countries. The five-year survival is $50 \%$ in developing countries, where it is $66 \%$ in developed ones. ${ }^{5}$

\section{Bethesda Terminology Changes}

There were minimal changes relating to terminology itself. The 2014 Bethesda terminology is summarized in Table 1.

\section{AIMS AND OBJECTIVES}

To assess the clinician utility of The Bethesda System Reporting of cervical and vaginal epithelial abnormalities.

\section{MATERIAL AND METHODS}

This is a retrospective observational study carried out in the Department of Pathology, Pt. Jawaharlal Nehru Memorial Medical College, Raipur (CG) in the duration 2007, 2008, 2009 and 2014. A total number of 1700 conventional Pap smears were collected from women attending the Gynae OPD in the Department of Obstetrics and Gynaecology, Dr Bhim Rao Ambedkar Memorial Hospital, Raipur CG.

Slides were smeared, immediately fixed with 95\% alcohol along with completely filled requisition form were sent to cytology section. All smears were stained by Papanicolaou stain and observed under the microscope 10x, $40 \mathrm{x}$ and 100x objectives. Reported with application of the 2014 Bethesda System for evaluation of cervical/vaginal lesions. 


\section{Inclusion Criteria}

Women of age between 21- 70 years with presenting complaints, e.g. white discharge, pain in abdomen, burning micturition, post coital bleeding, intermenstrual bleeding, well preserved smear with complete clinical details and willing to Pap screening.

\section{Exclusion Criteria}

Below 20 years and above 70 years, hystrectomy patient (Vault), diagnosed case of squamous cell carcinoma with or without therapy, infertility cases (Hormonal evaluation), during menstruation, pregnancy, post-partum, air dried smear, incomplete clinical details.

\section{RESULTS}

In this study total number of 1700 Pap smear were screened during the period of 26 months; 1532 (90.00\%) smears were satisfactory for evaluation.

Table no. 2 show year-wise distribution of cases from 2007 to 2014 in year 2007 (January to June); total no. of 526 pap smear were retrieved, $480(91.25 \%)$ were satisfactory for evaluation; in year 2008 (January-July) total no. of pap smear 554 retrieved, $482(87.0 \%)$ were satisfactory for evaluation; in year 2009 (January to June) out of 230 pap smear 202 (87.82\%) were satisfactory for evaluation; in year 2014 (June to Dec) out of 390 pap smear 365 (94.35\%) were satisfactory for evaluation.

Fig. 1 shows pattern of cervical/vaginale lesions in Pap smear, 35\% were normal, 56\% were NILM and 9\% were epithelial abnormalities in Pap smear.

Fig. 2 shows pattern of cervical/vaginale lesions reported as NILM. Out of 852 cases of NILM, 757 (44.52\%) were non-specific inflammatory smear, $35(2.05 \%)$ were of Trichomonas vaginalis and $20(1.17 \%)$ were of candidiasis.

Table no. 3 shows age-wise distribution of smear of NILM. In this study the age of patient ranged from 21-70 years, $20.56 \%$ of patient were in 21-30 years of age group followed by $\%$ of patient were in 31-40 years of age. Maximum number of epithelial cell abnormalities observed between 31-40 years of age group. (Figure 4).

Fig. 3 shows out of $136(8 \%)$ cases of epithelial cell abnormalities, 66(3.88\%) were LSIL, 50(2.94\% ) HSIL, $9(0.52 \%)$ cases were frank squamous cell carcinoma, $8(0.47 \%)$ cases ASCUS, $2(0.11 \%)$ cases in AGUS, $1(0.05 \%)$ case in AGUS-H.

\section{DISCUSSION}

In present study out of 1700 smears $90 \%$ were satisfactory for evaluation, similar findings reported by Shrivastava $M$ et al. 6 in 2011 (91.02\%). Vijay Kumar Bodal et al. ${ }^{7}$ in 2014 96\% and Verma I et al. ${ }^{8}$ in 2014 reported $97.6 \%$ of satisfactory smears. (Table 4).

In present study age ranged from 21 to 70 years, similar study reported by Jain V et al..$^{9}$ in 2010 20-80 years, but other authors reported range of various age group (Table 5).

In present study non-specific inflammatory lesions shows highest percentage $93.5 \%$ in comparision of other authors Kishor H, Suryawanshi et al. ${ }^{10}$ in 2013, Shrivastava M et al. ${ }^{6}$ in 2011 and Vijay Kumar Bodal et al. ${ }^{7}$ in 2014.

In present study, candidiasis was reported in $2.4 \%$ of cases similar study reported by Shrivastava M et al. ${ }^{6}$ in 2014 (Table 6).

In present study, $4.3 \%$ of LSIL, $3.26 \%$ of HSIL, $0.58 \%$ of SCC, $0.5 \%$ of ASCUS, $0.13 \%$ of AGUS and $0.06 \%$ of AGUS-H. These findings are not correlated with other authors.

We have a very low rate of ASCUS and AGUS and AGUS$\mathrm{H}$ indicating that this diagnosis is made very selectively in present study. The clinical follow-up of ASCUS is variable. The options being repeat cytology, immediate colposcopy or
HPV DNA testing. Most of our patients have colposcopically directed biopsy as the next procedure.

\section{CONCLUSION}

Pap smear has been regarded as the gold standard for cervical cancer screening programs. In present study, maximum number of intraepithelial lesions observed between the age group of 31-40 years, so thorough screening is required in women of sexually active age group.

Papanicolaou (Pap) smear is a safe, non-invasive and effective method for detection of pre-cancerous, cancerous and non-cancerous changes in the cervix. In developing countries like India, there is a great need for mass screening program.

We recommend multiple clinical setups with these facilities to be available to all and Government should be providing funds.

\section{REFERENCES}

1. Kline TS. The Papanicolaou smear. A brief historical perspective and where we are today. Arch Pathol Lab Med 121:205-210, 1997.

2. Schumann JL, O'Connor DM, Covell JL, Greening SE. Pap smear collection devices. Technical, clinical, diagnostic and legal considerations associated with their use. Diagn Cytopathol 8:492-503, 1992.

3. National Cancer Institute Workshop. The Bethesda System for Reporting Cervical/Vaginal Cytologic Diagnoses. Acta Cytol 37:115-124, 1993.

4. Walboomers JMM, Jacobs, MV, Manos MM, Bosch FX, Kummer JA, Shah KV, Snijder PJF, Peto J, Meijer CJLM and Munoz N (1999). Human papillomavirus is a necessary cause of invasive cervical cancer worldwide. J Pathol 189:12-19.

5. Ferlay J, Bray F, Pisani P, Parkin DM. Cancer incidence, mortality and prevalence worldwide [database]. Lyon, France: International agency for research on cancer (IARC); Cancer Base 2005;5:2.

6. Shrivastava M et al., Shrivastava OP et al. Pattern of Cervical Smear Cytology in Rural Medical College: Pravara Med Rev 2011;3(1).

7 Bodal KV et al., Brar KB et al. Correlation of Pap Smear with Histopathological findings in Malignant and nonmalignant Lesions of Cervix. Global Journal of Medical research: E Gynecology and Obstetrics Volume 14 Issue 4 Version 1.0 Year 2014. Online ISSN: 2249-4618 \& Print ISSN: 0975-5888.

8 Verma I, Jain V, Kaur T. Bethesda System for Cervical Cytology in Unhealthy Cervix. Journal of Clinical and Diagnosis Research. 2014 Sep, Vol-8(9):0C26-OC30.

9 Jain V and Vyas AS. Cervical neoplasia-cyto-histological correlation (Bethesda System) A Study of 276 Cases. J Cytol Histol 1:106. Vol 1, Issue 2.

10 Suryawanshi KH et al., Dravid NV et al. Evaluation of Pattern of Cervical Cytology in a Tertiary Care Hospital A Four Years Study; International Journal of Health Sciences \& Research (www.ijhsr.org) Vol.3; Issue: 7; July 2013.

11 Nayar Ritu et al., Wilbur DC et al. The Pap test and Bethesda 2014; ActaCytologica 2015;59:121-132.

12 Bahala et al. Cytological pattern of cervical papaicolaou smears in Eastern Region of Saudi Arabia. Journal of cytology 2011;28(4):174-177.

13 Atilgan et al. Evaluation of cervical cytological abnormalities in Turkish population. Indian journal of Pathology and Microbiology 2012;55(1):52-55. 
Table 1

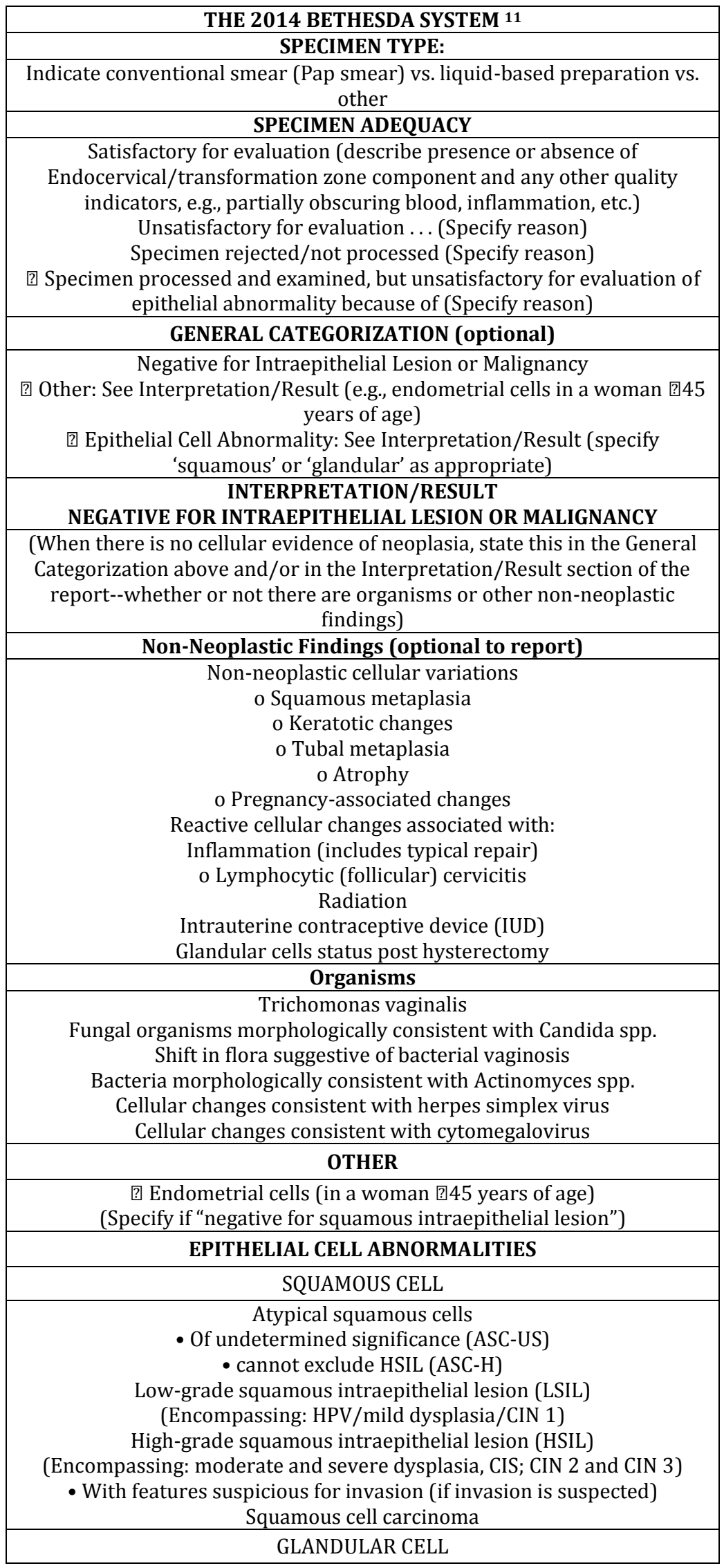




\begin{tabular}{c} 
Atypical \\
• Endocervical cells (NOS or specify in comments) \\
• Endometrial cells (NOS or specify in comments) \\
- Glandular cells (NOS or specify in comments) \\
Atypical \\
• Endocervical cells, favor neoplastic \\
- Glandular cells, favor neoplastic \\
Endocervical adenocarcinoma in situ \\
Adenocarcinoma \\
- Endocervical \\
• Endometrial \\
• Extrauterine \\
- Not otherwise specified (NOS) \\
\hline ADJUNCTIVE TESTING \\
\hline OTHER MALIGNANT NEOPLASMS: (Specify) \\
\hline Provide a brief description of the test method(s) and report the result so \\
that it is easily understood by the clinician. \\
\hline COMPUTER-ASSISTED INTERPRETATION OF CERVICAL CYTOLOGY \\
\hline If case examined by an automated device, specify device and result. \\
\hline EDUCATIONAL NOTES AND COMMENTS APPENDED TO CYTOLOGY \\
REPORTS (optional) \\
\hline Suggestions should be concise and consistent with clinical follow-up \\
guidelines published by professional organizations (References to \\
relevant publications may be included).
\end{tabular}

\begin{tabular}{|c|c|c|}
\hline Duration & $\begin{array}{c}\text { Total no. of } \\
\text { Pap Smear (1700) }\end{array}$ & $\begin{array}{c}\text { Satisfactory for } \\
\text { Evaluation } \\
\text { (1532) }\end{array}$ \\
\hline $\begin{array}{c}\text { 2007 January - } \\
\text { June (6 months) }\end{array}$ & 526 & $480(91.25 \%)$ \\
\hline $\begin{array}{c}\text { 2008 January- } \\
\text { July (7 months) }\end{array}$ & 554 & $482(87.00 \%)$ \\
\hline $\begin{array}{c}\text { 2009 January - } \\
\text { June (6 months) }\end{array}$ & 230 & $202(87.82 \%)$ \\
\hline $\begin{array}{c}\text { 2014 June- } \\
\text { December (7 } \\
\text { months) }\end{array}$ & 390 & $368(94.35 \%)$ \\
\hline \multicolumn{2}{|c|}{ Table 2: Shows Year-Wise Distribution of Cases } \\
\hline
\end{tabular}

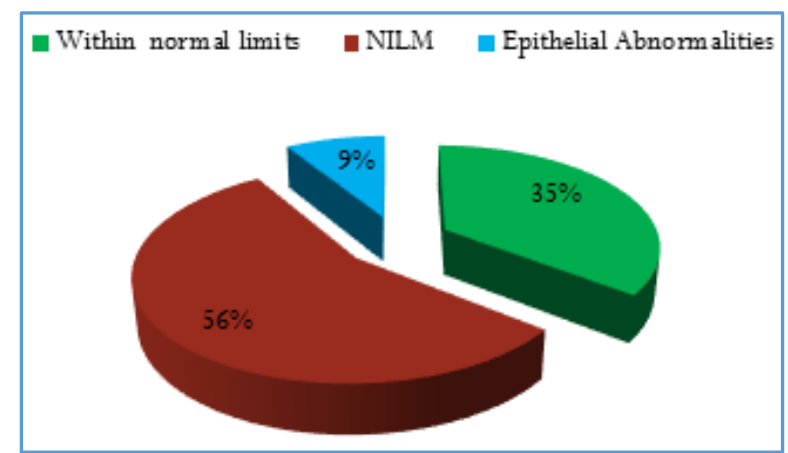

Fig.1: Shows Pattern of Cervical/Vaginal Lesions in Pap Smear

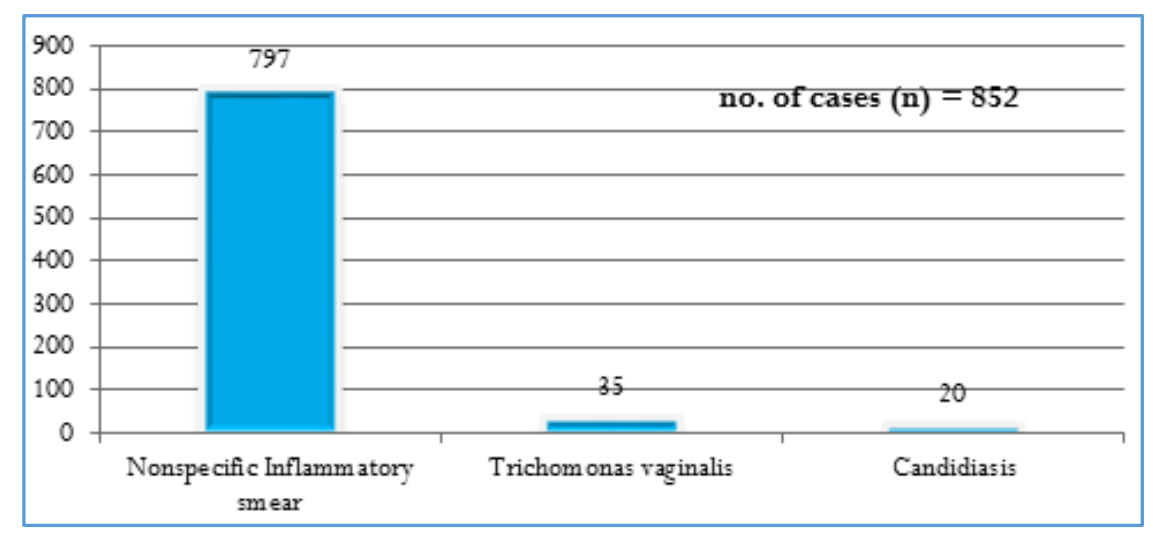

Fig. 2: Shows Pattern of Cervical/Vaginal Lesion reported as NILM

\begin{tabular}{|c|c|c|c|}
\hline Years & $\begin{array}{c}\text { Nonspecific } \\
\text { Inflammatory } \\
\text { Smear }\end{array}$ & $\begin{array}{c}\text { Trichomonas } \\
\text { Vaginalis }\end{array}$ & Candidiasis \\
\hline $21-30$ & $315(20.56 \%)$ & $14(0.91 \%)$ & $06(0.39 \%)$ \\
\hline $31-40$ & $300(19.58 \%)$ & $11(0.71 \%)$ & $07(0.45 \%)$ \\
\hline $41-50$ & $132(8.61 \%)$ & $09(0.58 \%)$ & $04(0.26 \%)$ \\
\hline $51-60$ & $35(2.28 \%)$ & $01(0.06 \%)$ & $03(0.19 \%)$ \\
\hline $61-70$ & $15(0.97 \%)$ & 0 & 0 \\
\hline \multicolumn{3}{|c|}{ Table 3: Shows Age-wise Distribution of Smear of NILM } \\
\hline
\end{tabular}




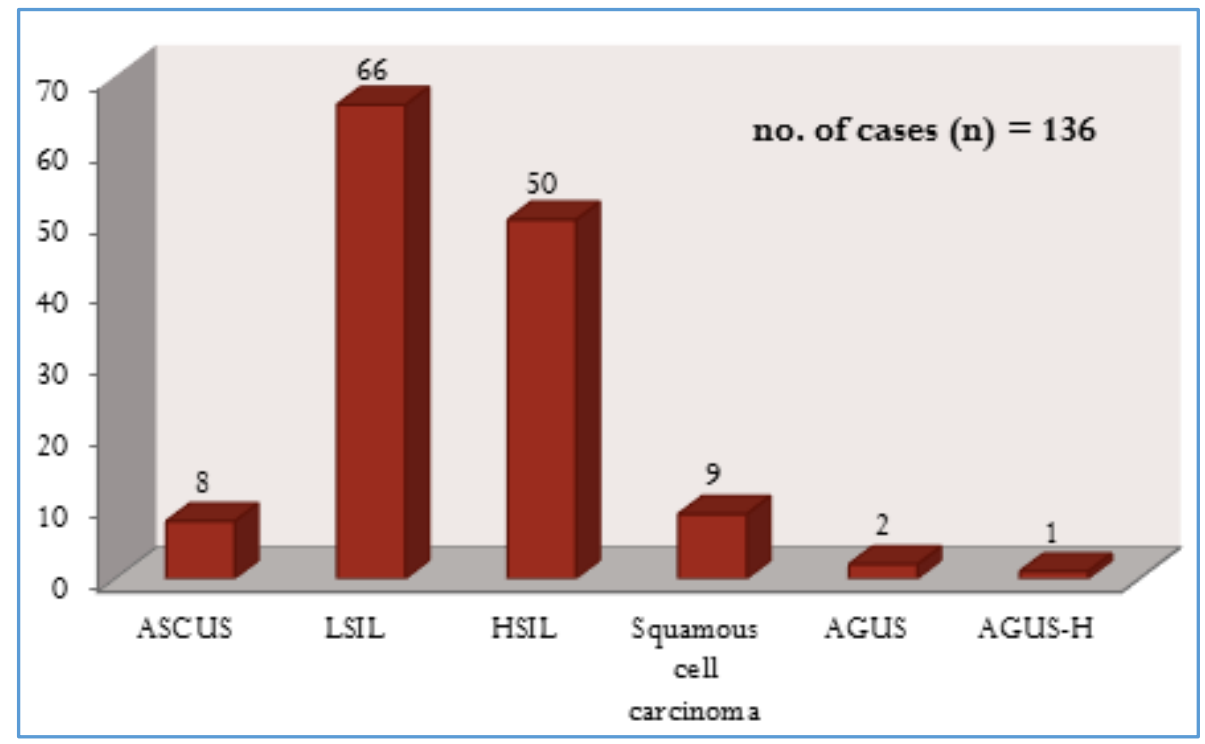

Fig. 3: Shows Distribution of Epithelial Cells Abnormalities

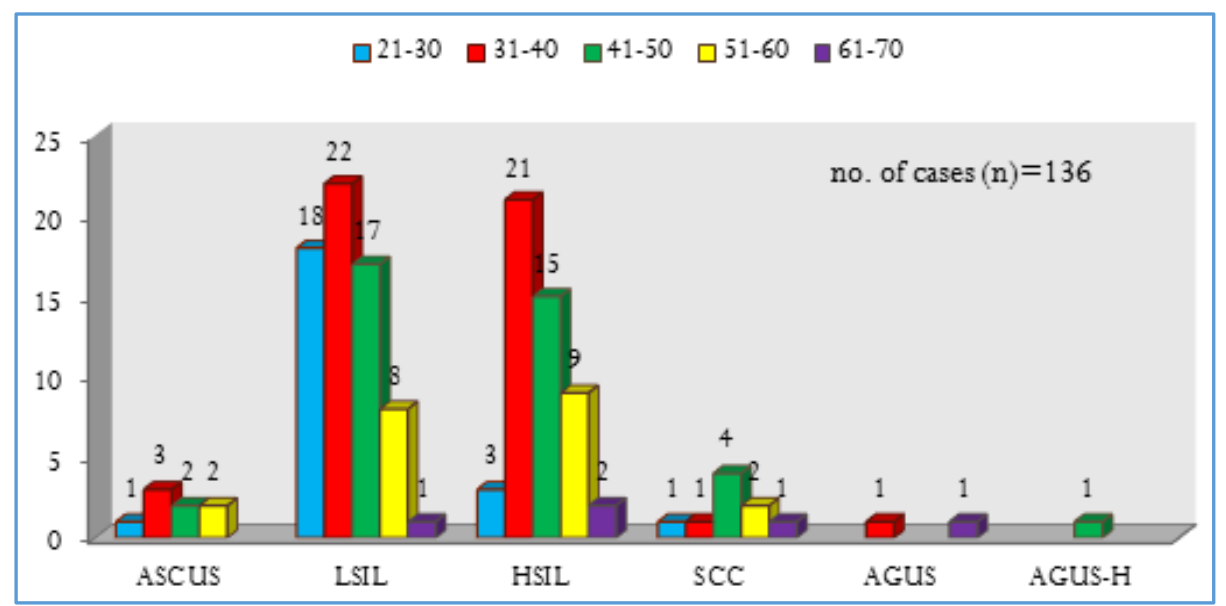

Fig. 4: Shows Age-Wise Distribution of Epithelial Cell Abnormalities

Maximum number of epithelial cell abnormalities observed between 31-40 years of age group.

\begin{tabular}{|c|c|c|c|}
\hline Author & Year & $\begin{array}{c}\text { Total } \\
\text { no. } \\
\text { of Case }\end{array}$ & $\begin{array}{c}\text { Satisfactory } \\
\text { Smear }\end{array}$ \\
\hline Shrivastava M et al. ${ }^{6}$ & 2011 & 680 & $91.02 \%$ \\
\hline $\begin{array}{c}\text { Vijay Kumar } \\
\text { Bodal et al. }\end{array}$ & 2014 & 200 & $96 \%$ \\
\hline Verma I et al. ${ }^{8}$ & 2014 & 125 & $97.6 \%$ \\
\hline Present study & 2015 & 1700 & $90.00 \%$ \\
\hline \multicolumn{3}{|c|}{ Table 4: Shows Comparison of Satisfactory } \\
Smears of Various Studies \\
\hline
\end{tabular}

\begin{tabular}{|c|c|c|}
\hline Author & Year & $\begin{array}{c}\text { Age Group } \\
\text { (Years) }\end{array}$ \\
\hline Shrivastava M et al. $^{6}$ & 2011 & $<20->50$ \\
\hline Jain V et al. $^{9}$ & 2010 & $20-80$ \\
\hline $\begin{array}{c}\text { Vijay Kumar } \\
\text { Bodal et al. }\end{array}$ & 2014 & $31-60$ \\
\hline Present study & 2015 & $21-70$ \\
\hline \multicolumn{2}{|c|}{ Table 5: Shows Comparison of Age Group of } \\
Various Studies \\
\hline
\end{tabular}

\begin{tabular}{|c|c|c|c|c|}
\hline Author & Year & $\begin{array}{c}\text { Nonspecific } \\
\text { Inflammatory Smear }\end{array}$ & $\begin{array}{c}\text { Trichomonas } \\
\text { Vaginalis }\end{array}$ & Candidiasis \\
\hline Kishor H. Suryawanshi et al. ${ }^{10}$ & 2013 & $920(76.67 \%)$ & $12(1.0 \%)$ & $08(0.67 \%)$ \\
\hline Shrivastava M et al. ${ }^{6}$ & 2011 & $176(28.16 \%)$ & $123(19.68 \%)$ & $15(2.40 \%)$ \\
\hline Vijay Kumar Bodal et al. ${ }^{7}$ & 2014 & $118(59.0 \%)$ & & \\
\hline Present study & 2015 & $797(93.5 \%)$ & $35(4.1 \%)$ & $20(2.4 \%)$ \\
\hline
\end{tabular}




\begin{tabular}{|c|c|c|c|c|c|c|c|}
\hline Author & Year & ASCUS & LSIL & HSIL & SCC & AGUS & AGUS-H \\
\hline${\text { Bahala et al. }{ }^{12}}^{2}$ & 2011 & $5.61 \%$ & $0.16 \%$ & $1.28 \%$ & $0.64 \%$ & $0.48 \%$ & \\
\hline Shrivastava M et al. & 2011 & $4.96 \%$ & $7.36 \%$ & $3.52 \%$ & $1.60 \%$ & $1.12 \%$ & \\
\hline Atilgan et al. ${ }^{13}$ & 2012 & $1.9 \%$ & $0.5 \%$ & $0.1 \%$ & $0.0 \%$ & $0.2 \%$ & \\
\hline Verma I et al. ${ }^{8}$ & 2014 & $4.80 \%$ & $5.60 \%$ & $0.80 \%$ & $0.80 \%$ & $0.80 \%$ & $0.80 \%$ \\
\hline Present study & 2015 & $0.5 \%$ & $4.30 \%$ & $3.26 \%$ & $0.58 \%$ & $0.13 \%$ & $0.06 \%$ \\
\hline
\end{tabular}

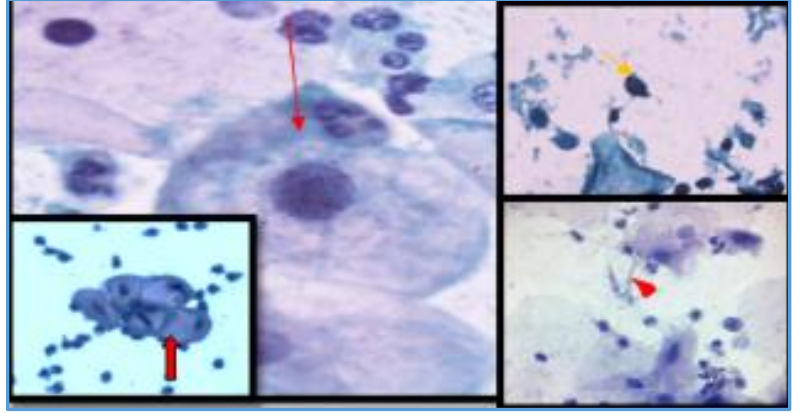

Photomicrogaph of acute cervicitis changes in a smear, acute Inflammatory exudation of polymorphs around and within the epithelial group $(\downarrow)$. Candida hyphae $(\emptyset)$, koilocytic atypia (U), Trichomonas vaginalis organism ( $\downarrow$ ) (PAP x400).

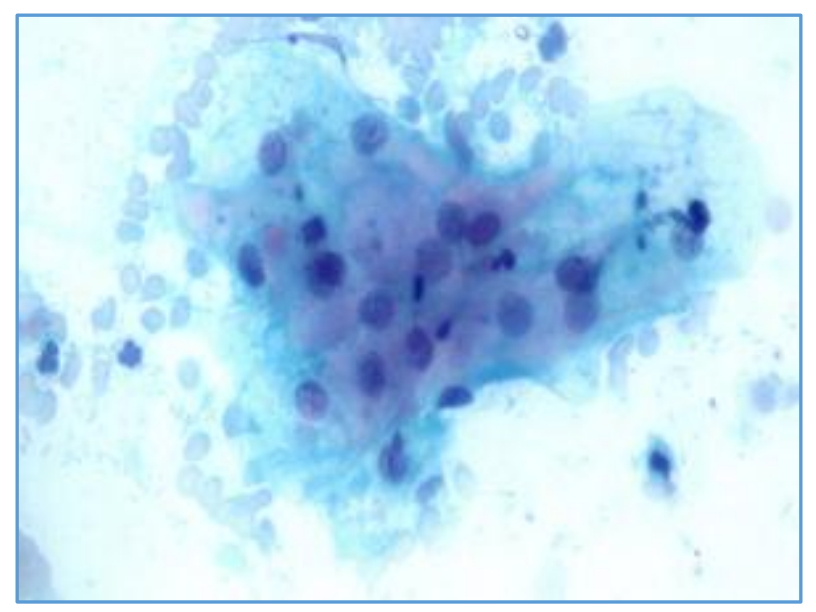

Photomicrograph of LSIL shows varying nuclear enlargement, abnormal chromatin pattern and mild irregularities of outline in inflammatory background (PAP x400).

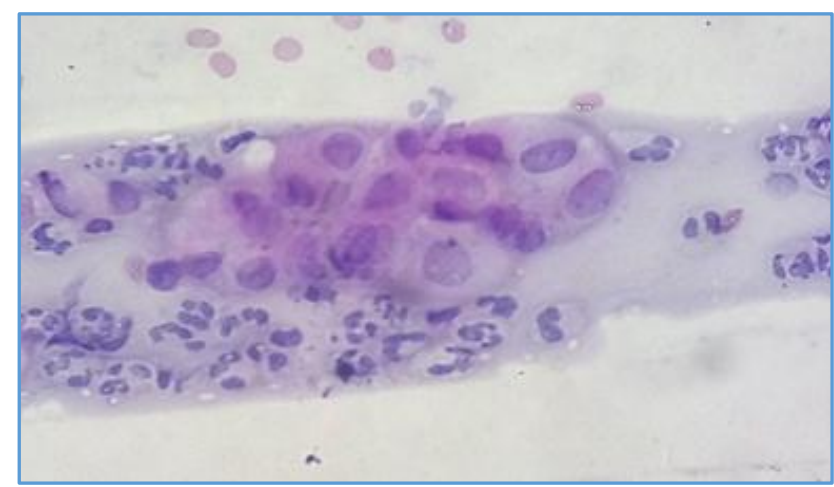

Photomicrograph of HSIL show marked hyperchromasia of nucleus in the centre, abnormal chromatin pattern and narrow band of cytoplasm (PAPx1000).

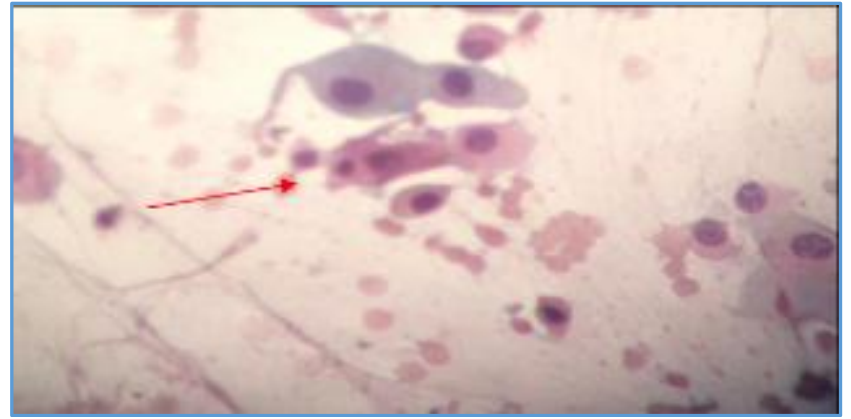

Photomicrograph of Pap smear of a case of squamous cell carcinoma showing small severly dyskaryotic cells with scanty cytoplasm, which shows keratinisation in cells. The background 'diatheses of leucocytes and cell debris (Papx400).

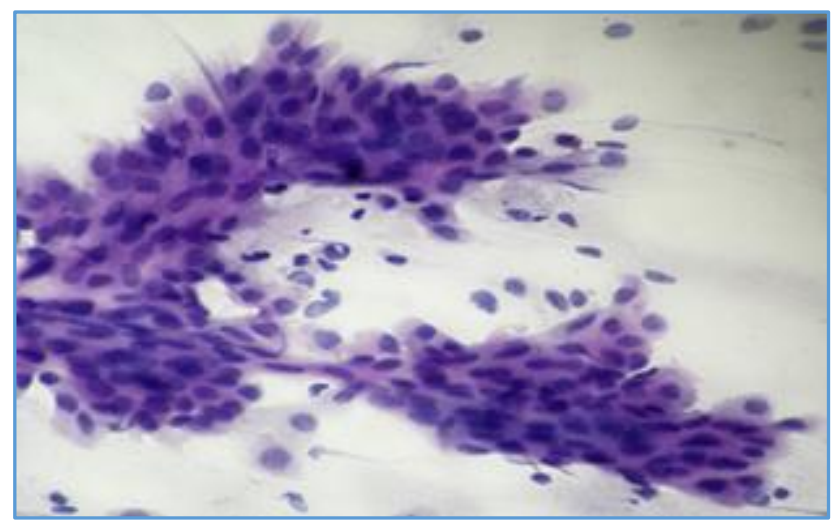

Photomicrograph of pap smear of a case of AGUS-H showing the individual atypical endocervical cells are hyperchromatic with coarsely clumped chromatin. They show the characteristic feathering of the nuclei at the edge of the cluster (PAP x400). 